\title{
Neuromedin Beta: P73T Polymorphism in Overweight and Obese Subjects
}

\author{
J. SPÁLOVÁ ${ }^{1}$, H. ZAMRAZILOVÁ ${ }^{1}$, J. VČELÁK ${ }^{1}$, M. VAŇKOVÁ ${ }^{1}$, P. LUKÁŠOVÁ ${ }^{1}$, \\ M. HILL ${ }^{1}$, K. HLAVATÁ ${ }^{1}$, P. ŠRÁMKOVÁ ${ }^{2}$, M. FRIED ${ }^{2}$, B. ALDHOON ${ }^{1,3}$, \\ M. KUNEŠOVÁ ${ }^{1}$, B. BENDLOVÁ ${ }^{1}$, V. HAINER ${ }^{1}$ \\ ${ }^{1}$ Institute of Endocrinology, ${ }^{2}$ Clinical Centre ISCARE I.V.F., ${ }^{3}$ Department of Cardiology, Institute \\ for Clinical and Experimental Medicine, Prague, Czech Republic
}

Received November 12, 2007

Accepted January 17, 2008

On-line February 13, 2008

\begin{abstract}
Summary
Neuromedin beta (NMB) is a member of the bombesin-like peptide family expressed in brain, gastrointestinal tract, pancreas, adrenals and adipose tissue. The aim of our study was to compare the frequency of P73T polymorphism in overweight and obese patients (37 men: age $50.6 \pm 11.7$ years, BMI $41.1 \pm 7.8 \mathrm{~kg} / \mathrm{m}^{2} ; 255$ women: age $49.0 \pm 11.9$ years, BMI $37.9 \pm 6.8 \mathrm{~kg} / \mathrm{m2}$ ) with that of healthy normal weight subjects (51 men: age $28.2 \pm 7.1$ years, BMI $22.3 \pm 2.0 \mathrm{~kg} / \mathrm{m}^{2} ; 104$ women: age $29.1 \pm 9.1$ years, BMI $21.5 \pm 1.9$ $\mathrm{kg} / \mathrm{m}^{2}$ ) and to investigate the polymorphism's influence on anthropometric, nutritional and psychobehavioral parameters in overweight/obese patients both at the baseline examination and at a control visit carried out 2.5 years later, regardless of the patient's compliance with the weight reduction program. No significant differences in the genotype distribution were demonstrated between normal weight and overweight/obese subjects. Male $T$ allele non-carriers compared to $T$ allele carriers had higher energy $(p=0.009)$, protein $(p=0.018)$ and fat $(p=0.002)$ intakes and hunger score $(p=0.015)$ at the beginning of treatment. Male $T$ allele non-carriers had a more favorable response to weight management at the follow-up, as they exhibited a significant reduction in waist circumference, energy intake and depression score as well as a significant increase in dietary restraint. No significant differences between carriers and non-carriers were demonstrated in women at the baseline examination. Both female $T$ allele carriers and non-carriers demonstrated similar significant changes in nutritional parameters and in restraint score at the follow-up. Nevertheless, only female non-carriers showed a significant decrease in the hunger score.
\end{abstract}

\section{Key words}

Neuromedin beta $\bullet$ Obesity $\bullet$ Gene polymorphism $\bullet$ Eating behavior - Nutrient intake • Weight loss

\section{Corresponding author}

Hana Zamrazilová, Institute of Endocrinology, Národní třída 8, 116 94 Prague 1, Czech Republic. E-mail: hzamrazilova@endo.cz

\section{Introduction}

Neuromedin beta $(N M B)$ is a member of the bombesin-like peptide family, a subfamily of ranatensins. These peptides are initially released from the gastrointestinal tract in response to food ingestion and bridge the gut and brain, through neurocrine means, to inhibit further food intake. Northern blot analysis revealed two $N M B$ gene transcripts of $750-850$ bases in human brain and gastrointestinal tissues with high expression levels in the hypothalamus, stomach, colon and low levels in cerebellum, pancreas, adrenals and adipose tissue (Ohki-Hamazaki 2000). NMB was identified in the hypothalamus (Krane et al. 1988), where afferent signals reflecting the nutritional state and efferent pathways that control feeding behavior and energy expenditure are integrated (Oeffner et al. 2000). NMB exerts its effect by binding to $N M B$ receptor, a G-protein coupled receptor (Ohki-Hamazaki 2000).

As shown in Figure 1, human $N M B$ is encoded by a 121-amino acid precursor consisting of an $\mathrm{N}$ terminal hydrophobic signal sequence followed by the prohormone $N M B-32$ and then a carboxy-terminal extension peptide (Oeffner et al. 2000). The gene for this precursor is localized on chromosome 15 (15q22.3-q23) and is comprised of three exons. This chromosome region contains a gene for the Bardet-Biedl syndrome (BBS) type 4 (Bruford et al. 1997). BBS is a rare disease described in the early 1920s (Biedl 1922) which is associated with severe obesity and congenital abnormalities such as retinal dystrophy, polydactyly, 


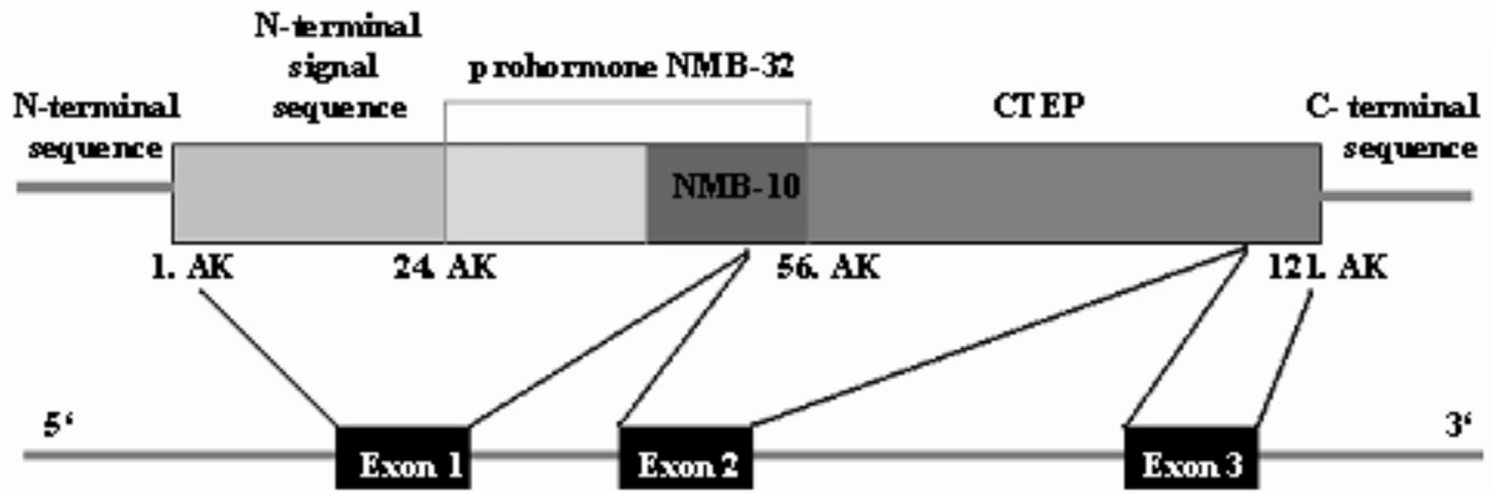

Fig. 1. The structure of human neuromedin beta gene (CTEP - Carboxy-Terminal Extension Peptide)

renal anomalies and hypogonadism in males. BBS is characterized by an autosomal recessive mode of inheritance (Beales et al. 1997).

It has been shown that weight loss maintenance is significantly influenced by psychobehavioral factors such as eating behavior assessed by the Eating Inventory and the level of depression evaluated by the Beck Depression Inventory (Hainer et al. 2005, Vogels et al. 2005, Kabrnová-Hlavatá et al. 2008). Eating Inventory evaluates three factors: dietary restraint, dietary disinhibition and hunger (Stunkard and Messick 1985). Dietary restraint is a conscious behavior aimed at limiting food intake. Disinhibition characterizes eating behavior of a person prone to non-compliance with a weight loss regimen and to overeating in response to stress, increased alcohol intake, anxiety, depression etc. Hunger score quantifies perceived hunger. Different contributions of hereditary components in determination of the factors of the Eating Inventory have been demonstrated in the Québec family study (Provencher et al. 2003). The heritability of disinhibition and susceptibility to hunger was found to be $19 \%$ and $32 \%$, respectively, whereas the heritability of cognitive restraint was not statistically significant. Bouchard et al. (2004) found a significant association between the missense polymorphism P73T (or C253A) in exon 2 of the $N M B$ and levels of disinhibition and susceptibility to hunger, increased body weight, body mass index (BMI), waist circumference and fat mass. The primary aim of our study was to compare the frequences of $N M B$ P73T polymorphisms in overweight and obese patients with that of healthy normal weight subjects. The second aim of our study was to investigate the influence of $\mathrm{P} 73 \mathrm{~T}$ polymorphism on selected anthropometric, nutritional and psychobehavioral parameters in overweight/obese patients both at their baseline visit to the Obesity Management Centre and at the follow-up visit carried out 2.5 years later regardless of compliance with the weight reduction program.

\section{Methods}

\section{Subjects}

The overweight and obese patients (37 men: age $50.6 \pm 11.7$ years, BMI $41.1 \pm 7.8 \mathrm{~kg} / \mathrm{m}^{2} ; 255$ women: age $49.0 \pm 11.9$ years, BMI $37.9 \pm 6.8 \mathrm{~kg} / \mathrm{m}^{2}$ ) were examined in the Obesity Management Centre of the Institute of Endocrinology in Prague and in the Obesity Management Unit of the Clinical Centre ISCARE IVF in Prague. Frequency of the P73T polymorphism was compared with healthy normal weight subjects without family history of morbid obesity or diabetes type 2 (51 men: age $28.2 \pm 7.1$ years, BMI $22.3 \pm 2.0 \mathrm{~kg} / \mathrm{m}^{2} ; 104$ women: age $29.1 \pm 9.1$ years, BMI $21.5 \pm 1.9 \mathrm{~kg} / \mathrm{m}^{2}$ ). Essential characteristics of the overweight and obese patients are presented in Table 1.

Our study was carried out over a 3-year period. The comprehensive weight management program included low energy diet (recommended daily energy deficit cca $2.5 \mathrm{MJ}$ ), increased physical activity (recommended 30 minutes of aerobic exercise per day such as walking, cycling etc.) and behavioral lifestyle modification provided by a psychologist. All patients underwent a control examination 2.5 years after the baseline visit without regard to their adherence to the weight reduction program or their attendance in regular check-ups. Even the patients who dropped out from the study (in $39 \%$ patients less than three visits per year were recorded) were able to participate at the control visit.

Anthropometric parameters (body weight, height, waist and hip circumferences) were measured according to the WHO recommendations (WHO Expert Committee 1995). Body composition (fat mass \%, fat free 


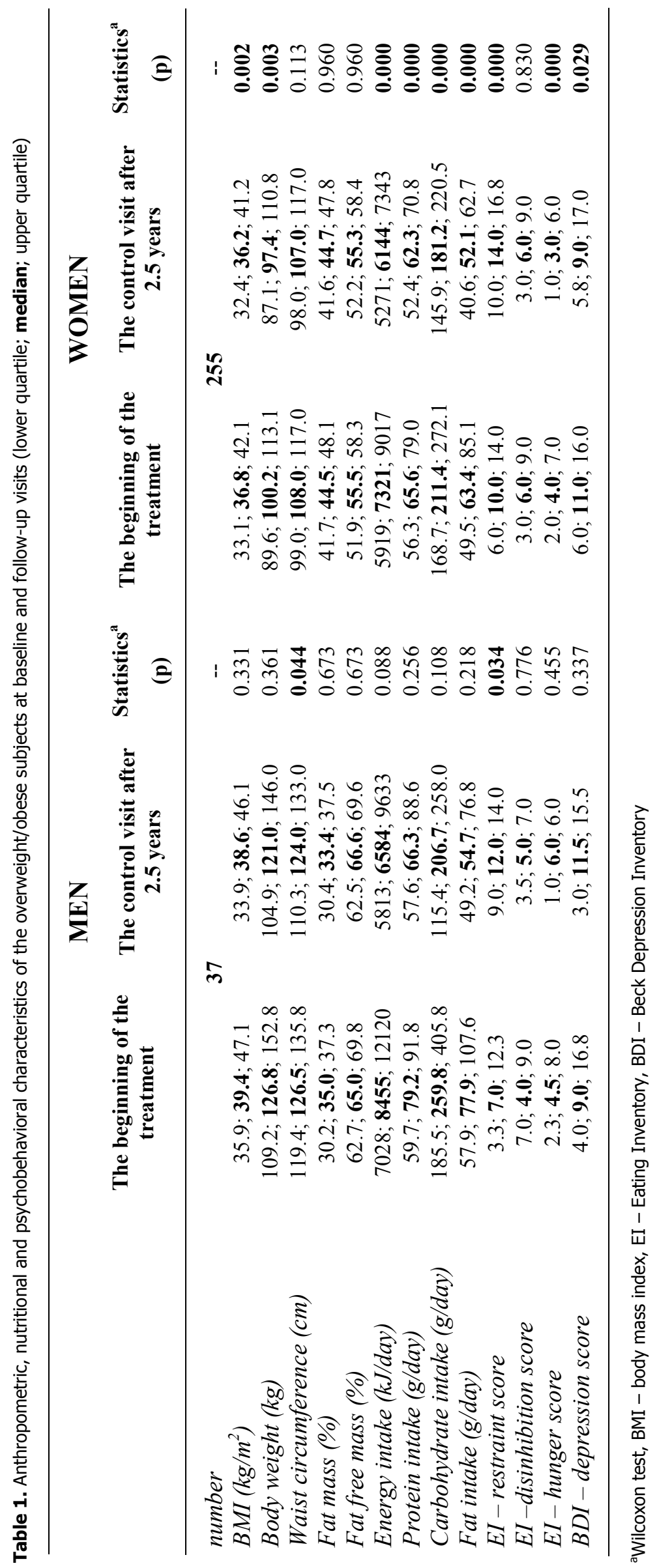


mass \%) was assessed using a bipedal - bimanual bioimpedance analyser - TANITA BC-418MA.

Daily energy and macronutrients (protein, carbohydrate, fat) intakes were evaluated from a oneweek dietary record, which was performed at the baseline and follow-up visits. A computerized version of the Czech Nutrition File „Vyziva“, which includes almost 3000 food items, was used for dietary intake assessment.

A validated Czech version of the Eating Inventory (Stunkard and Messick 1985) was used to measure dietary restraint, disinhibition and susceptibility to hunger. This Three Factor Eating Questionnaire was used in our previous studies involving obese patients (Hainer et al. 2005) and in a quota sample of Czech adults (Hainer et al. 2006). The depression score was measured by the Beck Depression Inventory (Beck et al. 1961).

The study was conducted in accordance with the Declaration of Helsinki and was approved by the Ethic Committee of the Institute of Endocrinology. All subjects signed informed consent before the study initiation.

\section{Genotyping}

Genomic DNA was isolated from peripherial blood leukocytes using the QIAamp ${ }^{\circledR}$ DNA Blood Kit (QIAGEN, Germany). Genomic DNA was amplified by polymerase chain reaction (PCR; T-Gradient Cycler, Biometra, Germany). Reactions were performed in a final volume of $12 \mu \mathrm{l}$. Primers were designed in accordance with Oeffner et al. (2000). In order to find variants of the P73T polymorphism (PP, PT, TT) the sequencing method was used (ALFExpress II, Amersham Pharmacia Biotech, USA). For screening of P73T polymorphism the Single Strand Conformation Polymorphism (SSCP) method was employed, using control genotypes in every run (ALFExpress II, Amersham Pharmacia Biotech, USA). Allele determinations were performed independently by two experienced persons. Detailed procedures of the methods used are available from the corresponding author.

\section{Statistical analysis}

Genotype frequencies were tested by the $\chi^{2}$-test. The differences between groups were evaluated using the robust Mann-Whitney test, while the differences between the beginning of the treatment and the control visit at the 2.5-year follow-up were assessed by Wilcoxon's paired robust test. The PC programs NCSS 2004, QC.Expert 2.7 and Microsoft Excel 2007 were used for statistical analysis.

\section{Results}

Table 1 summarizes essential anthropometric, nutritional and psychobehavioral characteristics of the overweight/obese subjects at the baseline and follow-up visits. The cohort of men was made up of less individuals, most likely due to the fact that Czech men tend to not be as motivated as women to participate in a long term life style modification program. In men a significant reduction in waist circumference was revealed at the follow-up visit. In both genders an observed significant increase in dietary restraint score could have contributed to a better control of energy intake. A minor but significant decrease in body weight and BMI in women at the follow-up visit might reflect a significant decrease in energy and nutrient intakes as well as a decline in hunger and depression scores.

Table 2 shows the frequencies of genotypes (PP, PT, TT) in overweight and obese population and in healthy normal weight persons. No significant differences in the frequencies of genotypes were demonstrated between the two groups studied $\left(\chi^{2}=2.08, \mathrm{p}=0.353\right)$.

Due to the low frequency of TT homozygotes, overweight and obese patients were divided into two groups - $\mathrm{T}$ allele non-carriers (homozygotes $\mathrm{PP}$ ) and $\mathrm{T}$ allele carriers (heterozygotes PT together with homozygotes TT). Table 3 shows anthropometric, psychobehavioral and nutritional parameters before the treatment and after the 2.5-year follow-up period in overweight and obese men classified as $\mathrm{T}$ allele carriers or non-carriers. Male $\mathrm{T}$ allele non-carriers had higher energy intake $(p=0.009)$, protein intake $(p=0.018)$, fat intake $(p=0.002)$ and hunger score $(p=0.015)$ at the beginning of treatment in comparison with male $\mathrm{T}$ allele carriers. After the follow-up period, significant decreases in waist circumference $(p=0.021)$, energy intake $(\mathrm{p}=0.038)$, carbohydrate intake $(\mathrm{p}=0.038)$, dietary restraint $(p=0.021)$ and score of depression $(p=0.032)$ were observed in male $\mathrm{T}$ allele non-carriers. Changes in energy and carbohydrate intakes over the follow-up period significantly differed between male $\mathrm{T}$ allele carriers and non-carriers ( $\mathrm{p}=0.043, \mathrm{p}=0.034$ respectively). $\mathrm{T}$ allele carriers increased and $\mathrm{T}$ allele non-carriers decreased energy intake and carbohydrate consumption. Maximum weight loss observed at follow-up was higher in $\mathrm{T}$ allele non-carriers than in $\mathrm{T}$ allele carriers (median: 15.1 vs. $11.5 \mathrm{~kg}$ ). However, the difference in weight loss between the two groups was not statistically significant $(\mathrm{p}=0.365)$. 
Table 2. The frequencies of genotypes in overweight/obese patients and in normal weight subjects

\begin{tabular}{lllllll}
\hline & $\begin{array}{l}\text { PP } \\
\text { overweight } \\
\text { and obese } \\
\mathbf{n}(\mathbf{\%})\end{array}$ & normal weight & $\begin{array}{l}\text { PT } \\
\text { overweight } \\
\text { and obese } \\
\mathbf{n}(\%)\end{array}$ & normal weight & $\begin{array}{l}\text { TT } \\
\text { overweight } \\
\text { and obese } \\
\mathbf{n}(\%)\end{array}$ & normal weight \\
\hline $\begin{array}{l}\text { men } \\
\text { women }\end{array}$ & $17(45.9)$ & $28(54.9)$ & $18(48.6)$ & $20(39.2)$ & $2(5.4)$ & $3(5.9)$ \\
total & $128(50.2)$ & $59(56.7)$ & $108(42.4)$ & $36(34.6)$ & $19(7.5)$ & $9(8.7)$ \\
\hline
\end{tabular}

$x^{2}=2.08, p=0.353$ (for total numbers)

Table 4 shows anthropometric, psychobehavioral and nutritional parameters before the treatment and after the 2.5-year follow-up period in overweight and obese women who were classified as T-allele carriers or noncarriers. At the beginning of the treatment no significant differences between carriers and non-carriers were demonstrated in women. In neither men nor women did P73T polymorphism affect the maximum weight loss achieved (median: 9.9 vs. $10.0 \mathrm{~kg}, \mathrm{p}=0.434$ ). Both female $\mathrm{T}$ allele carriers and non-carriers exhibited significant decreases in energy, protein, carbohydrate and fat intakes and increases in restraint scores. However, a decrease in BMI and body weight was revealed in $\mathrm{T}$ allele carriers only. In contrast to $\mathrm{T}$ allele carriers, female non-carriers significantly decreased in the hunger score. Nevertheless, changes in anthropometric, psychobehavioral and nutritional parameters at the follow-up were not significant for either female $\mathrm{T}$ allele carriers or noncarriers.

\section{Discussion}

$N M B$ is a member of the bombesin-like peptides family. These peptides have many biological effects that may be related to eating behaviors and obesity (Bouchard et al. 2004). Monitoring P73T polymorphism in $N M B$ revealed many associations with dietary disinhibition, susceptibility to hunger and fat mass change over time (Bouchard et al. 2004). Recent results from the Québec Family Study confirmed a significant contribution of $N M B$ polymorphism to the adiposity changes in adult subjects with a wide range of adiposity (BMI range from 17.5 to $55.6 \mathrm{~kg} / \mathrm{m}^{2}$ ) who were followed over a period of 6-10 years (Bouchard et al. 2007). It was therefore considered possible that $N M B$ could play a role in the regulation of eating behavior and thus might affect body weight.
Several gene polymorphisms have been implicated in the determination of weight loss and weight loss maintenance (Hainer et al. 2008). As weight loss maintenance remains an essential target in weight loss strategies (Wadden et al. 2004), the aim of our study was to evaluate the influence of P73T NMB polymorphism on anthropometric, nutritional and psychobehavioral indexes in obese patients at baseline examination and at a 2.5year follow-up visit.

The frequency of P73T genotypes in our cohort was not different between healthy normal weight control group and overweight/obese subjects. Frequency of $\mathrm{T}$ allele in overweight/obese patients and in healthy control group was similar (28.8 \% vs. $25.8 \%$ ). This our finding confirms that of Oeffner et al. (2000), who monitored obese German children and adolescents, and also did not detect an association of the $\mathrm{T}$ allele to body weight. In their study frequencies of this allele in severely obese $(29.03 \%)$ were similar to those observed in underweight subjects $(26.60 \%)$. However, they revealed a significant association between the G401A polymorphism in the $N M B$ gene and body weight (Oeffner et al. 2000). Bouchard et al. (2004) who studied a randomized sample of the Québec population did not find significant differences in P73T genotypes with regard to body weight, BMI, waist circumference, fat mass $(\mathrm{kg})$, restraint score and intakes of macronutrients. However, TT homozygotes exhibited significantly higher level of disinhibition and hunger when compared to $\mathrm{P}$ allele carriers. TT homozygotes gained significantly more fat over a 6-year follow-up than PP homozygotes.

Our study demonstrated the influence of P73T polymorphism on anthropometric, nutritional and psychobehavioral parameters, esp. in men. At the beginning of the treatment male $\mathrm{T}$ allele non-carriers exhibited higher susceptibility to hunger $(p=0.015)$ and higher dietary disinhibition (of borderline significance 


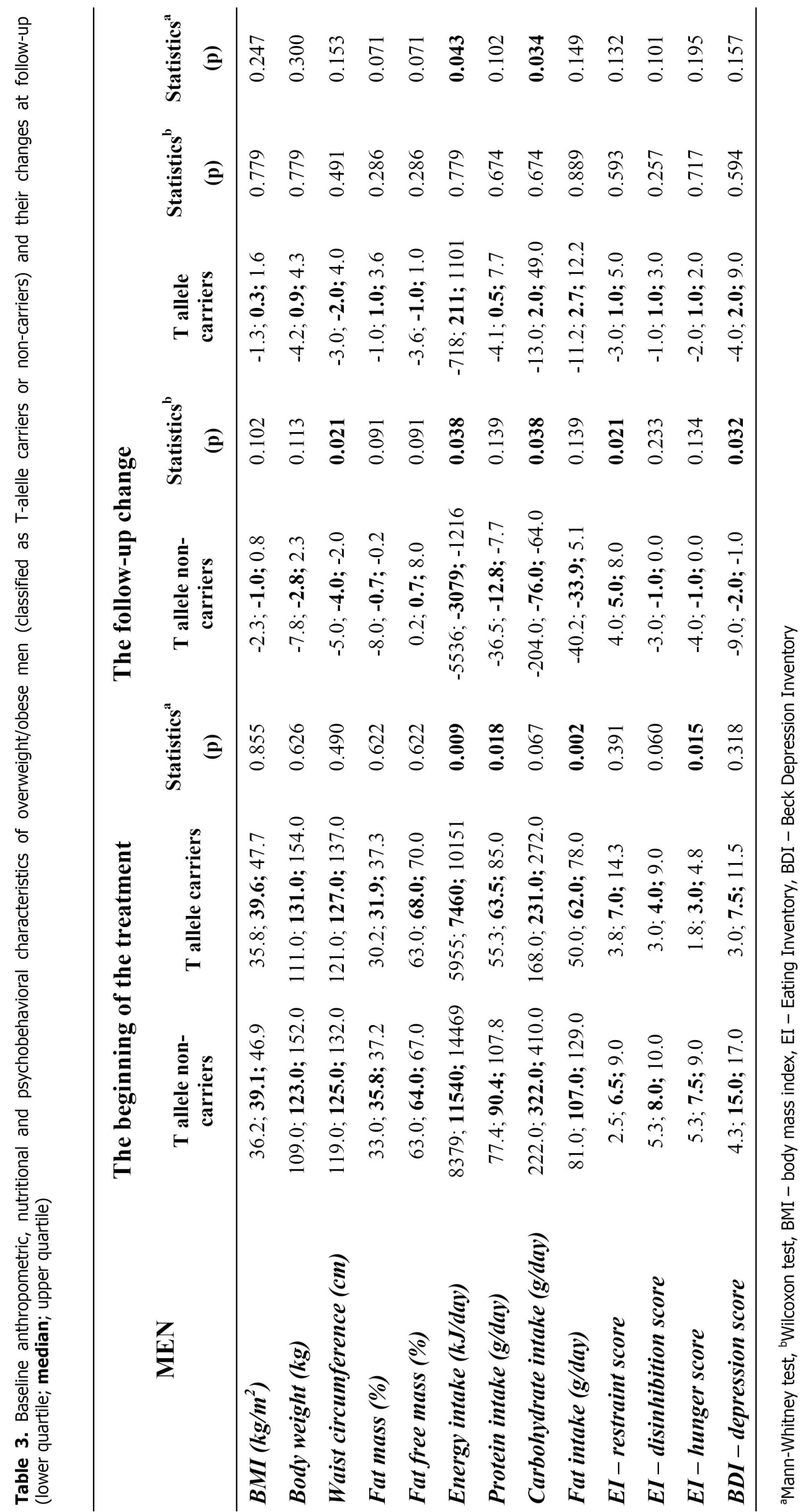




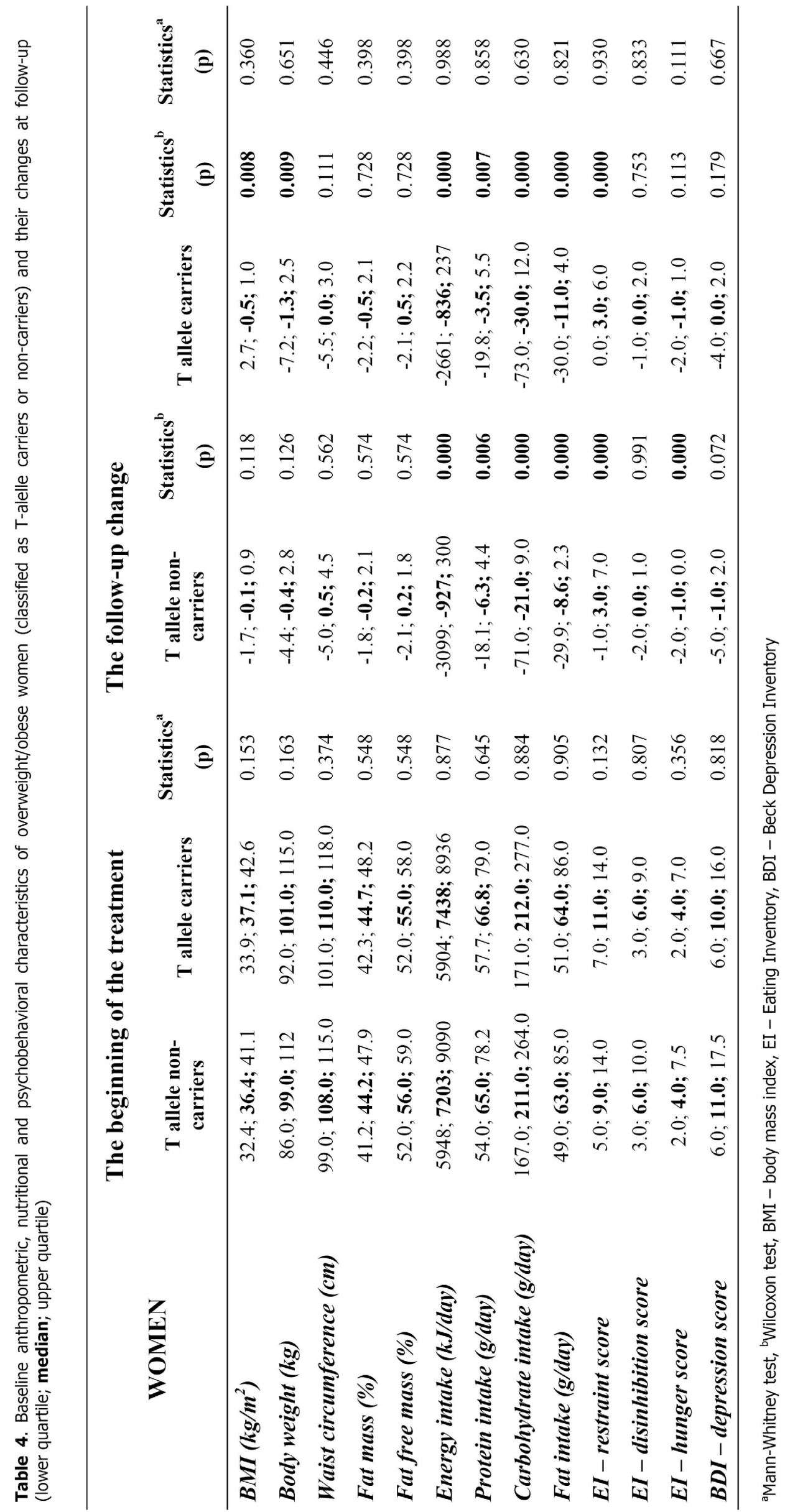


$\mathrm{p}=0.06)$ compared to $\mathrm{T}$ allele carriers. Higher baseline energy $(p=0.009)$, protein $(p=0.018)$ and fat $(p=0.002)$ intakes in $\mathrm{T}$ allele non-carriers probably reflected the higher hunger score. On the other hand, Bouchard et al. (2004) found that TT homozygotes had significant higher susceptibility to hunger than $P$ allele carriers. It should be taken into account that Bouchard et al. (2004), in contrast to our study, evaluated the items of the Eating Inventory in the whole cohort comprised of both genders while we conducted our evaluation in men and women separately. This our approach seems reasonable as significant gender differences in the items of the Eating Inventory have been demonstrated; restraint score being higher in women whereas disinhibition score and hunger score are higher in men (Hainer et al. 2006). However, if we evaluated overall changes at follow-up period we might support some of the conclusions of the study of Bouchard et al. (2004). T allele carriers seem to be disadvantaged in several aspects against non-carriers. In our cohort of obese males $\mathrm{T}$ allele non-carriers but not $\mathrm{T}$ allele carriers exhibited significant decreases in waist circumference and energy intake after the follow-up period. Observed concomitant increase in dietary restraint score and decrease in depression score in $\mathrm{T}$ allele non-carriers might contribute to reduction of energy intake and abdominal obesity assessed by waist circumference. The Québec Family Study, which followed subjects over a 6year period, demonstrated the highest increase of body weight, BMI, body fat (expressed both as $\mathrm{kg}$ and \%) and waist circumference in TT homozygotes when compared to other genotypes. In agreement with the results of Bouchard et al. (2004) it could be presumed that carrying the $\mathrm{T}$ allele is a disadvantage in terms of reduction of abdominal obesity and energy intake, however only in men.

In women, the baseline values for anthropometric measures, energy and macronutrient intakes, items of the Eating Inventory and Beck depression score did not differ between the $\mathrm{T}$ allele carriers and non-carriers. No significant differences in the maximum weight loss nor in the changes of anthropometric measures over follow-up period were shown between the female $\mathrm{T}$ allele carriers and noncarriers. However, a decrease in body weight and BMI was significant only in females who were $\mathrm{T}$ allele carriers and a decrease in hunger score achieved statistical significance in female $\mathrm{T}$ allele non-carriers. Inconsistency in the results obtained in men and women might be due to gender specific role of genes in the phenotypic manifestation of genotype. Such a gender specific role of genes as determinants of obesity development has recently been shown for perilipin gene (Qi et al. 2004) and for $\beta_{2}$-and $\beta_{3}$-adrenergic receptor genes (Ukkola et al. 2000, Corella et al. 2001).

Several differences in the character of the cohort (ethnicity, age, BMI) and design (duration of follow-up) of our study and in that of Bouchard et al. (2004) might explain different outcomes. We followed Czech overweight/obese subjects over 2.5-year period, whereas Bouchard et al. (2004) monitored a sample of genetically homogenous Québec adults over 6 years. Our subjects were on average 6.5 years older than those in the Bouchard's cohort (49.2 vs. 42.7 years) (Bouchard et al. 2004). It has been demonstrated that the effect of genes, which contributes to adiposity changes is stronger in the younger than in older subjects (Bouchard et al. 2007). The role of gender and age was confirmed in investigations into the influence of the PPARGC1A G482S polymorphism on the risk of obesity (Ridderstråle et al. 2006).

Our pilot study demonstrated some gender specific associations of $\mathrm{P} 73 \mathrm{~T}$ polymorphism of $N M B$ with eating behavior and weight changes at 2.5 -year follow-up. The results should be confirmed on large groups of men.

\section{Abbreviations \\ BBS Bardet-Biedl syndrome \\ BDI Beck Depression Inventory \\ BMI body mass index \\ DNA deoxyribonucleic acid \\ EI Eating Inventory \\ $N M B$ neuromedin beta}

\section{Conflict of Interest}

There is no conflict of interest.

\section{Acknowledgements}

This study was supported by the grants IGA MH CR NR/7800-4 and IGA MH CR NR/7809-5.

\section{References}

BEALES PL, WARNER AM, HITMAN GA, THAKKER R, FLINTER FA: Bardet-Biedl syndrome: a molecular and phenotypic study of 18 families. J Med Genet 34: 92-98, 1997. 
BECK AT, WARD CH, MENDELSON M, MOCK J, ERBAUGH J: An inventory for measuring depression. Arch Gen Psychiatry 4: 561-571, 1961.

BIEDL A: A pair of sisters with adiposo-genital dystrophy (in German). Dtsch Med Wochenschr 48: 1630, 1922.

BOUCHARD L, DRAPEAU V, PROVENCHER V, LEMIEUX S, CHAGNON Y, RICE T, RAO DC, VOHL MC, TREMBLAY A, BOUCHARD C, PÉRUSSE L: Neuromedin B: a strong candidate gene linking eating behaviors and susceptibility to obesity. Am J Clin Nutr 80: 1478-1486, 2004.

BOUCHARD L, TREMBLAY A, BOUCHARD C, PÉRUSSE L: Contribution of several candidate genes polymorphisms in the determination of adiposity changes: results from the Québec Family Study. Int $J$ Obes 31: 891-899, 2007.

BRUFORD EA, RIISE R, TEAGUE PW, PORTER K, THOMSON KL, MOORE AT, JAY M, WARBURG M, SCHINZEL A, TOMMERUP N, TORNQVIST K, ROSENBERG T, PATTON M, MANSFIELD DC, WRIGHT AF: Linkage mapping in 29 Bardet-Biedl syndrome families confirms loci in chromosomal regions 11q13, 15q22.3-q23, and 16q21. Genomics 41: 93-99, 1997.

CORELlA D, GUILLÉN M, PORTOLÉS O, SORLÍ JV, ALONSO V, FOLCH J, SÁIZ C: Gender specific associations of the Trp64Arg mutation in the beta3-adrenergic receptor gene with obesity-related phenotypes in a Mediterranean population: interaction with a common lipoprotein lipase gene variation. $J$ Intern Med 250: 348-360, 2001.

HAINER V, KUNEŠOVÁ M, BELLISLE F, HILL M, BRAUNEROVÁ R, WAGENKNECHT M: Psychobehavioral and nutritional predictors of weight loss in obese women treated with sibutramine. Int J Obes 29: 208-216, 2005.

HAINER V, KUNEŠOVÁ M, BELLISLE F, PAŘÍZKOVÁ J, BRAUNEROVÁ R, WAGENKNECHT M, LAJKA J, HILL M, STUNKARD A: The Eating Inventory, body adiposity and prevalence of diseases in a quota sample of Czech adults. Int J Obes 30: 830-836, 2006.

HAINER V, ZAMRAZILOVÁ H, SPÁLOVÁ J, HAINEROVÁ I, KUNEŠOVÁ M, ALDHOON B, BENDLOVÁ B: Role of hereditary factors in weight loss and its maintenance. Physiol Res, Suppl 1, 2008.

KRANE IM, NAYLOR SL, HELIN-DAVIS D, CHIN WW, SPINDEL ER: Molecular cloning of cDNAs encoding the human bombesin-like peptide neuromedin B. Chromosomal localization and comparison to cDNAs encoding its amphibian homolog ranatensin. J Biol Chem 263: 13317-13323, 1988.

KABRNOVÁ-HLAVATÁ K, HAINER V, GOJOVÁ M, HLAVATÝ P, KOPSKÝ V, NEDVÍDKOVÁ J, KUNEŠOVÁ M, PAŘÍZKOVÁ J, WAGENKNECHT M, HILL M, DRBOHLAV J: Calcium intake and the outcome of short-term weight management. Physiol Res 2008 (In press)

OEFFNER F, BORNHOLDT D, ZIEGLER A, HINNEY A, GÖRG T, GERBER G, GOLDSCHMIDT HP, SIEGFRIED W, WRIGHT A, HEBEBRAND J, GRZESCHIK KH: Significant association between a silent polymorphism in the neuromedin B gene and body weight in German children and adolescents. Acta Diabetol 37: 93-101, 2000.

OHKI-HAMAZAKI H: Neuromedin beta. Prog Neurobiol 62: 297-312, 2000.

PROVENCHER V, PÉRUSSE L, DRAPEAU V, TREMBLAY A, DEPRÉS J, LEMIEUX S: Familial resemblence in eating behaviors in men and women from the Québec Family Study. $J$ Am Diet Assoc 102 (suppl 2): A-35, 2003.

QI L, SHEN H, LARSON I, SCHAEFER EJ, GREENBERG AS, TREGOUET DA, CORELLA D, ORDOVAS JM: Gender-specific association of a perilipin gene haplotype with obesity risk in a white population. Obes Res 12: 1758-1765, 2004.

RIDDERSTRÅLE M, JOHANSSON LE, RASTAM L, LINDBLAD U: Increased risk of obesity associated with the variant allele of the PPARGC1A Gly482Ser polymorphism in physically inactive elderly men. Diabetologia 49: 496-500, 2006.

STUNKARD AJ, MESSICK S: The three-factor eating questionnaire to measure dietary restraint, disinhibition and hunger. J Psychosom Res 29: 71-83, 1985. 
UKKOLA O, RANKINEN T, WEISNAGEL SJ, SUN G, PÉRUSSE L, CHAGNON YC, DESPRÉS JP, BOUCHARD $\mathrm{C}$ : Interactions among the alpha2-, beta2-, and beta3-adrenergic receptor genes and obesity-related phenotypes in the Quebec Family Study. Metabolism 49: 1063-1070, 2000.

VOGELS N, DIEPVENS K, WESTERTERP-PLANTENGA MS: Predictors of long-term weight maintenance. Obes Res 13: 2162-2168, 2005.

WADDEN TA, BUTRYN ML, BYRNE KJ: Efficacy of lifestyle modification for long-term weight control. Obes Res 12 (Suppl): 151S-162S, 2004.

WHO EXPERT COMMITTEE Physical status: The use and interpretation of anthropometry. Geneva: WHO Technical Series Report No. 854, Geneva, 1995, pp 452. 